\title{
BUDAYA TRI HITA KARANA SEBAGAI PEMODERASI PENGARUH PRINSIP GOOD CORPORATE GOVERNANCE PADA KINERJA LEMBAGA PERKREDITAN DESA DI KOTA DENPASAR
}

\author{
I Putu Arya Mulyawan', \\ Dewa Gede Wirama ${ }^{2}$ \\ I Dewa Nyoman Badera ${ }^{3}$ \\ ${ }^{1,2,3}$ Fakultas Ekonomi dan Bisnis Universitas Udayana (Unud), Bali, Indonesia \\ Email: aryamulyawan8@gmail.com/ Telp.081805681622
}

\begin{abstract}
ABSTRAK
Penelitian ini menganalisis pengaruh good corporate governance (GCG) pada kinerja Lembaga Perkreditan Desa (LPD) serta untuk menguji apakah budaya tri hita karana (THK) memoderasi pengaruh tersebut. GCG diukur dengan menggunakan kuesioner mengenai lima prinsip GCG yaitu transparency, accountability, respostibility, independency, dan fairness. Budaya THK diukur dengan menggunakan kuesioner mengenai tiga aspek THK yaitu parahyangan, pawongan dan palemahan. Kinerja LPD diukur menggunakan CAMEL yang diperoleh dari laporan LPLPD Kota Denpasar per Desember 2016. Teknik analisis data yang digunakan untuk menguji pengaruh GCG pada kinerja LPD adalah analisis regresi linier sederhana dan untuk menguji apakah budaya THK memoderasi pengaruh GCG pada kinerja LPD digunakan moderated regression analysis. Hasil analisis data menunjukkan bahwa GCG berpengaruh positif pada kinerja LPD, dan Budaya THK memperkuat pengaruh GCG pada kinerja LPD di Kota Denpasar.
\end{abstract}

Kata kunci: Good Corporate Governance, Tri Hita Karana, Kinerja

\begin{abstract}
This study analyses the influence of good corporate governance (GCG) on the performance of Lembaga Perkreditan Desa (LPD) and to test whether Tri Hita Karana (THK) Culture moderate that influence. GCG is measured by questionnaires on five GCG principles, namely transparency, accountability, responsibility, independency, and fairness. THK is measured by questionnaires on three aspects of THK namely parahyangan, pawongan, and palemahan. LPD's performance is measured by CAMEL scores as reported by LPLPD Kota Denpasar as of December 2016. Data analysis technique used to test the effect of GCG on LPD's performance is simple linear regression analysis. A moderated regression analysis is used to analyse whether THK moderate the influence of GCG on LPD's performance. The result of the data analysis shows that GCG has a positive effect on LPD's performance, and THK strengthens the influence of GCG on LPD's performance in Denpasar City.
\end{abstract}

Keywords: Good Corporate Governance, Tri Hita Karana, Performance 


\section{PENDAHULUAN}

Pembangunan nasional merupakan rangkaian dari pembangunan seluruh aspek yang berkesinambungan. Untuk dapat menunjang pembangunan nasional diperlukan perekonomian yang sehat yang harus dimulai dari tingkatan paling dasar, yaitu tingkat desa. Salah satu lembaga keuangan pedesaan yang dikembangkan terutama di Bali adalah Lembaga Perkreditan Desa (LPD).

Pembentukan LPD di Provinsi Bali berawal dari hasil seminar kredit pedesaan yang diselenggarakan di Kota Semarang pada tanggal 20 sampai dengan 21 Februari 1984. Seminar ini menyimpulkan bahwa kehadiran suatu lembaga perkreditan pedesaan dipandang sangat tepat guna menjangkau masyarakat kecil atau miskin di pedesaan sehingga upaya untuk meningkatkan taraf hidup masyarakat golongan tersebut dapat tercapai. Pemilihan desa adat sebagai basis dalam pembentukan LPD di Provinsi Bali adalah dikaitkan dengan usaha untuk melestarikan dan mengembangkan desa adat yang ada di Bali.

LPD memiliki peranan yang sangat strategis bagi masyarakat setempat karena selama ini telah melayani Usaha Mikro Kecil (UMK) dan masyarakat pedesaan melalui pelayanan jasa keuangan yang dilakukan sesuai dengan kebutuhan nasabah, yaitu prosedurnya yang sederhana, tidak berbelit-belit, proses singkat, serta lokasi yang dekat dengan nasabah pedesaan (Yudana dkk., 2015).

Meskipun secara umum LPD dapat dikatakan berhasil dalam menjalankan fungsi dan tujuannya, namun keberhasilan ini tidak dirasakan oleh seluruh LPD yang ada. Di Kota Denpasar, dari 35 LPD yang ada, tidak semua memiliki predikat kesehatan dalam posisi sehat. Menurut data dari LPLPD (Lembaga 
Pemberdayaan Lembaga Pekreditan Desa) Kota Denpasar per 31 Desember 2016, terdapat dua LPD yang masuk dalam kategori cukup sehat, yaitu LPD Oongan dan LPD Serangan, sedangkan 33 (tiga puluh tiga) LPD dikategorikan sehat.

Kinerja LPD belakangan ini dapat dikatakan mengagumkan, yang terlihat dari laporan yang dibuat oleh LPLPD Kota Denpasar sepanjang tahun 2016 dimana di bulan Januari 2016 LPD mengelola aset sebesar Rp 1.399 milyar dan meningkat di bulan Desember 2016 menjadi Rp 1.626 milyar dan dilihat dari sisi laba ada peningkatan dari Rp 45,300 milyar diawal tahun 2016 menjadi Rp 70,218 milyar di pengujung tahun 2016 (LPLPD Kota Denpasar, 2016).

Peningkatan dari kinerja organisasi yang berdampak pada tercapainya tujuan organisasi harus didukung dengan adanya sebuah tata kelola yang baik atau good corporate governance (GCG). GCG dapat membantu dalam usaha pencegahan terjadinya skandal dalam perusahaan, kecurangan serta kejahatan yang berhubungan dengan hutang piutang dari organisasi (Todorovic, 2013). Oleh karena itu penerapan prinsip GCG sangat diperlukan dalam menjalankan bisnis. Prinsip-prinsip tersebut adalah transparency, accountability, responsibility, independency, dan fairness, dan merupakan prinsip yang harus selalu dipegang teguh oleh setiap organisasi yang ingin mewujudkan tata kelola yang baik.

Dalam setiap organisasi, GCG merupakan salah satu faktor kunci yang menentukan kesehatan sistem dan kemampuannya untuk bertahan dalam guncangan ekonomi. Kesehatan organisasi bergantung pada bagaimana individu yang ada didalamnya dan hubungan antara setiap individu yang ada. Dengan demikian, GCG yang baik akan berkontribusi pada pembangunan ekonomi 
berkelanjutan dengan meningkatkan kinerja organisasi (Sarbah dan Xiao, 2015). Walaupun LPD dapat dikatakan sebagai bisnis yang memiliki jangkauan bisnis hanya dalam satu desa adat, namun harus diingat bahwa tata kelola yang baik akan dapat memberikan keuntungan yang lebih bagi sebuah organisasi bisnis.

Beberapa penelitian telah dilakukan mengenai hubungan antara GCG dan kinerja perusahaan memberikan hasil yang beragam. Menurut Rahmatika dkk. (2015), ukuran, transparansi, kemandirian, akuntabilitas, pertanggungjawaban, dan kewajaran berpengaruh positif pada kinerja keuangan. Senada dengan itu, Atmadja dkk. (2014) menyatakan bahwa terdapat pengaruh GCG pada kinerja LPD yang ada di Kabupaten Buleleng. Begitu pula dengan Dewi dan Putri (2014) yang mendapatkan hasil bahwa prinsip GCG berpengaruh positif pada kinerja keuangan LPD di Kabupaten Gianyar.

Berbanding terbalik dengan beberapa penelitian di atas, dalam penelitian berikut ini didapatkan hasil bahwa GCG tidak berpengaruh terhadap kinerja perusahaan. Kautsar dan Kusumaningrum (2015) serta Hartono dan Nungrahanti (2014) menyajikan bukti bahwa GCG tidak memiliki pengaruh pada kinerja perusahaan. Selain itu, Thuraisingam (2013) juga menyatakan bahwa tidak terdapat pengaruh yang signifikan antara GCG dan kinerja perusahaan yang diukur dengan return on assets dan return on equity.

Mengingat tidak konsistennya hasil penelitian mengenai pengaruh GCG pada kinerja maka diperkirakan ada variabel lain yang memoderasi pengaruh tersebut. Variabel pemoderasi yang dipertimbangkan dalam penelitian ini adalah Budaya Tri Hita Karana. Hubungan antara budaya tersebut dengan kinerja di 
antaranya diutarakan oleh Riana (2010) dan Surya dkk. (2014). Penggunaan budaya THK sebagai variabel pemoderasi di antaranya telah dilakukan oleh Adiputra (2014) yang menyatakan bahwa budaya THK memoderasi pengaruh kompleksitas tugas pada kinerja internal auditor di Kantor Inspektorat Provinsi Bali, sedangkan Mustikayani dan Dwirandra (2016) mendapatkan hasil bahwa budaya THK tidak memoderasi pengaruh kompleksitas tugas pada kinerja auditor.

Dalam sebuah organisasi, lingkungan kerja dan budaya yang menyenangkan mempunyai peranan penting dalam meningkatkan kinerja karyawan yang paling produktif (Suryadi dan Rosyidi, 2013). Untuk memaksimalkan kinerja, sebuah organisasi pada dasarnya juga harus memiliki pandangan bahwa kinerjanya dipengaruhi oleh nilai-nilai baik yang berasal dari kekuatan diri, lingkungan kerja, serta hubungan antar sesama pegawai (Adiputra, 2014). Oleh karena itu, pengaruh budaya lokal yang merupakan budaya yang sudah diketahui dan selalu dijalankan oleh semua orang yang ada di daerah tersebut sangatlah penting. Sebuah falsafah kultur Bali, Tri Hita Karana (THK) yang menekankan pada teori keseimbangan menyatakan bahwa masyarakat Hindu cenderung memahami diri dan lingkungannya sebagai sebuah sistem yang dikendalikan oleh nilai keseimbangan, dan diwujudkan dalam bentuk prilaku (Gunawan, 2009). Budaya THK merupakan kearifan lokal Bali yang digunakan sebagai landasan individu dalam setiap aktivitasnya, khususnya pada masyarakat desa adat yang merupakan pemilik LPD. Konsep kehidupan yang baik mengedepankan prinsip-prinsip kebersamaan, keselarasan dan keseimbangan antara tujuan ekonomi, pelestarian lingkungan dan budaya, estetika dan spiritual (Tenaya, 2007). 
Istilah THK tidak ada dalam kitab suci weda dan susatra Hindu lainnya. Adanya istilah ini merupakan kreativitas pemuka Agama Hindu khususnya di Bali yang akhirnya mampu memformulasikan berbagai konsep yang ada dalam ajaran Agama Hindu (Dwirandra, 2011). Istilah THK pertama kali muncul pada tanggal 11 November 1966, pada waktu diselenggarakannya Konfrensi Daerah I Badan Perjuangan Umat Hindu Bali yang bertempat di Perguruan Dwijendra Denpasar. Konfrensi tersebut diadakan berlandaskan kesadaran umat Hindu akan dharmanya untuk berperan serta dalam pembangunan bangsa menuju masyarakat sejahtera, adil dan makmur berdasarkan Pancasila. Kemudian istilah Tri Hita Karana ini berkembang, meluas dan memasyarakat (Adnyana, 2016).

THK memiliki konsep bahwa hubungan harmonis merupakan hal yang penting dalam menjalankan suatu kegiatan atau organisasi. Keyakinan atas keharmonisan ini telah menjadi tuntunan masyarakat hindu Bali untuk berperilaku yang melahirkan berbagai tindakan nyata yakni (a) keselarasan hubungan antara manusia dengan Ida Sang Hyang Widhi Wasa (Tuhan Yang Maha Esa) yang dikenal dengan istilah Parahyangan, (b) keselarasan hubungan dengan sesama manusia dikenal dengan istilah Pawongan, serta (c) keselarasan hubungan manusia dengan alam sekitar yang dikenal dengan istilah Palemahan. Inti dan hakekat dari ajaran THK adalah kerjasama dan keselarasan yang baik dari semua komponen yang berhubungan dengan suatu kegiatan atau organisasi. Selain itu juga didukung dengan adanya program Pemerintah Daerah Provinsi Bali yang menyelenggarakan Tri Hita Karana Awards yang semakin menumbuhkan 
implementasi ajaran THK dalam kehidupan sehari-hari terutama pada pekerjaan (Mustikayani dan Dwirandra, 2016).

Kinerja yang baik mengindikasikan bahwa tingkat kepercayaan masyarakat desa adat selaku sumber dan tujuan atas aliran dana yang dihimpun oleh LPD mengalami proses yang baik. Peraturan Gubernur Bali Nomor 11 Tahun 2013 tentang Petunjuk Pelaksanaan Peraturan Daerah Provinsi Bali Nomor 8 Tahun 2002 tentang Lembaga Perkreditan Desa sebagaimana telah diubah beberapa kali terakhir dengan Peraturan Daerah Provinsi Bali Nomor 4 Tahun 2012 tentang Perubahan Kedua Atas Peraturan Daerah Provinsi Bali Nomor 8 Tahun 2002 tentang Lembaga Perkreditan Desa dalam bagian keenam pasal 22 ayat 2 tentang penilaian kesehatan LPD menyatakan bahwa faktor penilaian kesehatan LPD didasarkan atas lima aspek berikut, yang lazim disebut dengan analisis CAMEL.

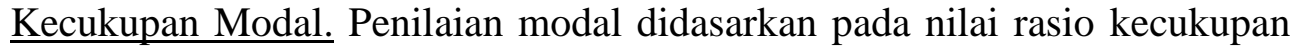
modal (capital adequacy ratio, disingkat CAR). Rasio ini merupakan perbandingan antara modal inti ditambah modal pelengkap dan aktiva tertimbang menurut risiko (ATMR). CAR adalah rasio yang memeperlihatkan seberapa jauh seluruh aktiva yang mengandung risiko (kredit, surat berharga, dan tagihan pada bank lain) ikut dibiayai dari dana modal sendiri, di samping dana-dana dari sumber di luar seperti dana masyarakat, pinjaman, dan lain-lain (Apriliana dan Utama, 2013).

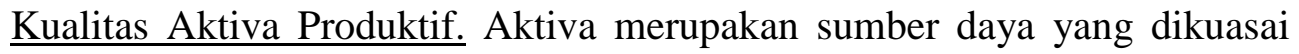
oleh perubahan sebagai akibat dari peristiwa masa lalu yang memberikan manfaat ekonomi di masa depan. 
Manajemen. Aspek ini dapat diartikan sebagai ilmu dan seni perencanaan, pengkoordinasian, dan pengawasan secara efektif dan efisien untuk mencapai tujuan yang telah ditetapkan.

Laba. Laba merupakan penilaian atas kemampuan perusahaan dalam menghasilkan laba melalui penggunaan aset yang dimiliki perusahaan.

Likuiditas. Aspek ini mencerminkan kemampuan dalam memenuhi semua permintaan dana oleh nasabah seperti memenuhi permintaan kredit tanpa ada penundaan dan kewajiban yang telah jatuh tempo.

Budaya yang positif dan kuat dapat menghasilkan kinerja dan pencapaian yang cemerlang bagi seorang individu, sedangkan budaya yang negatif dan lemah dapat menurunkan motivasi seorang individu dalam hal kinerja dan prestasinya (Ahmad, 2012). Beberapa penelitian telah dilakukan untuk mengetahui bagaimana pengaruh dari budaya dan kinerja organisasi seperti Ehtesham dkk. (2011) dan Ozigbo (2012) yang mendapatkan hasil bahwa budaya berpengaruh positif signifikan pada kinerja perusahaan.

Berdasarkan uraian sebelumnya, rumusan masalah dalam penelitian ini adalah (1) apakah prinsip-prinsip GCG mempengaruhi kinerja LPD yang ada di Kota Denpasar serta (2) apakah budaya THK memoderasi pengaruh prinsipprinsip GCG pada kinerja LPD yang ada di Kota Denpasar. Sesuai dengan rumusan tersebut maka tujuan penelitian ini adalah untuk menguji pengaruh prinsip-prinsip GCG pada kinerja LPD dan menguji apakah budaya THK 
memoderasi pengaruh prinsip-prinsip GCG pada kinerja LPD yang ada di Kota Denpasar.

Pentingnya GCG dalam organisasi modern adalah karena adanya pemisahan antara pemilik dan manajer dalam organisasi tersebut. Berdasarkan teori keagenan, kepentingan manajer tidak selalu selaras dengan kepentingan pemilik. Jensen dan Meckling (1976) menggunakan teori keagenan untuk menjelaskan hubungan antara prinsipal dan agen, di mana prinsipal memerintah agen untuk melaksanakan suatu pekerjaan atas nama prinsipal serta memberikan wewenang kepada agen untuk membuat keputusan yang terbaik bagi prinsipal. Masalah keagenan yang paling utama tercermin dalam perbedaan kepentingan dari setiap pemangku pentingan dalam sebuah organisasi (Khan, 2011). Dalam penelitian ini, prinsipal merupakan masyarakat desa adat sebagai pemilik LPD yang menuntut kinerja yang maksimal dari para agen, yaitu ketua LPD serta seluruh karyawan yang bekerja pada sebuah LPD.

Menurut Einsenhardt (1989) teori keagenan dilandasi atas beberapa asumsi yang diantaranya adalah asumsi tentang sifat manusia, asumsi keorganisasian dan asumsi informasi. Asumsi sifat manusia menekankan bahwa manusia memiliki sifat mementingkan diri sendiri (self-interest), memiliki keterbatasan rasional (bounded rationality) dan tidak menyukai risiko (risk aversion). Asumsi keorganisasian adalah adanya konflik antara anggota organisasi, efisiensi sebagai kriteria efektivitas dan adanya asimetri informasi antara prinsipal dan agen.

Teori keagenan mengasumsikan bahwa masyarakat desa adat sebagai prinsipal menuntut ketua serta seluruh karyawan LPD selaku agen untuk 
memaksimalkan kinerjanya dalam rangka menyelaraskan tujuan antara prinsipal dan agen. GCG dalam hal ini berperan sebagai alat yang digunakan oleh prinsipal untuk meminimalisir konflik keagenan yang dapat merugikan organisasi nantinya. GCG juga berkaitan dengan bagaimana para prinsipal dapat meyakini bahwa para agen akan memberikan keuntungan bagi mereka, yakin bahwa agen tidak menggelapkan dan menginvestasikan dana mereka pada projek-projek yang tidak menguntungkan prinsipal (Shleifer dan Vishny, 1997).

Penelitian ini mengkaji tentang bagaimana GCG dapat mempengaruhi kinerja dari sebuah LPD dengan budaya THK sebagai variabel pemoderasi. Teori keagenan mengasumsikan bahwa para nasabah LPD dan masyarakat desa adat sebagai prinsipal yang menuntut ketua serta seluruh karyawan LPD selaku agen untuk memaksimalkan kinerjanya dalam rangka menyelaraskan tujuan antara prinsipal dan agen. GCG dalam hal ini berperan sebagai alat yang digunakan oleh prinsipal untuk meminimalisir terjadinya konflik keagenan yang dapat merugikan organisasi nantinya.

GCG didefinisikan sebagai seperangkat peraturan yang menetapkan hubungan antara pemegang saham, pengurus, pihak kreditur, pemerintah, karyawan serta para pemegang kepentingan intern dan ekstern lainnya sehubungan dengan hak-hak dan kewajiban mereka, atau dengan kata lain sistem yang mengarahkan dan mengendalikan perusahaan (FCGI, 2003; Putri, 2012). GCG juga didefinisikan sebagai cara-cara manajemen perusahaan bertanggung jawab pada shareholder-nya. Setiap pengambilan keputusan di perusahaan 
haruslah dapat dipertanggungjawabkan dan keputusan tersebut mampu memberikan nilai tambah bagi shareholders lainnya.

Dalam melaksanakan kegiatan usahanya organisasi bisnis harus menganut kelima prinsip-prinsip GCG yang telah ditetapkan oleh KNKG (Budiarti, 2010). Prinsip-prinsip tersebut digunakan untuk mengukur seberapa jauh GCG telah diterapkan dalam perusahaan.

Menurut KNKG (2006) adapun lima prinsip yang menjadi pedoman pelaksanaan GCG, antara lain adalah yang pertama transparency (keterbukaan) merupakan suatu prinsip yang dilakukan untuk menjaga objektivitas dalam menjalankan bisnis dalam sebuah organisasi dengan jalan menyediakan informasi yang material dan relevan serta mudah diakses dan dipahami oleh pemangku kepentingan. Haque dkk. (2008) menyatakan bahwa sangat penting bagi perusahaan untuk membuat informasi keuangan dan non-keuangan yang mudah diakses oleh orang luar agar orang dapat membuat keputusan. Pengungkapan yang efektif dapat digunakan untuk mengevaluasi masa lalu kinerja manajemen, meramalkan perusahaan arus kas masa depan dan untuk memutuskan apakah profil risiko perusahaan masih dalam tingkat yang dapat diterima. Prinsip kedua adalah accountability (akuntabilitas) merupakan prinsip yang menyatakan bahwa organisasi harus dapat mempertanggungjawabkan kinerjanya secara transparan dan wajar. Untuk itu organisasi harus dikelola secara benar, terukur dan sesuai dengan kepentingan perusahaan dengan tetap memperhitungkan kepentingan pemegang saham dan pemangku kepentingan lain. Akuntabilitas merupakan prasyarat yang diperlukan untuk mencapai kinerja yang berkesinambungan. 
Prinsip ketiga dari GCG yang harus diterapkan adalah responsibility (responsibilitas). Prinsip ini mengharuskan organisasi untuk mematuhi peraturan perundang-undangan serta melaksanakan tanggung jawab terhadap masyarakat dan lingkungan sehingga dapat terpelihara kesinambungan usaha dalam jangka panjang dan mendapatkan pengakuan sebagai good corporate citizen. Dalam hal ini, selain berdasarkan Peraturan Daerah Provinsi Bali, keberadaan dan aktivitas dari LPD juga diatur berdasarkan awig-awig dan/atau pararem yang berlaku di desa adat setempat. Awig-awig dan/atau pararem yang dimaksud adalah yang dibuat oleh desa adat setempat dengan didampingi dan dibina oleh tim pembina penulisan awig-awig dari Pemerintah Provinsi Bali. Walaupun demikian, setiap desa adat memiliki ciri khas sendiri yang membedakannya dengan desa adat lainnya. Prinsip keempat adalah independency (kemandirian), prinsip ini menyatakan bahwa untuk melancarkan pelaksanaan asas GCG, organisasi harus dikelola secara independen sehingga masing-masing bagian dalam organisasi dapat saling mendomasi dan tidak dapat diintervensi oleh pihak lain. Dan yang kelima adalah fairness (kewajaran dan kesetaraan) merupakan peraturan yang adil dan setara dalam memenuhi kepentingan dari para pemangku kepentingan yang timbul berdasarkan pada peraturan perundang-undangan yang berlaku. Perusahaan harus senantiasa memperhatikan hak-hak para pemangku kepentingan berdasarkan asas kewajaran dan kesetaraan dalam rangka meningkatkan kinerja perusahaan ke arah yang lebih baik.

GCG merupakan faktor yang penting dalam menentukan nilai perusahan dan berpengaruh pada kinerja perusahaan seperti LPD. Rahmatika dkk. (2015) 
menyatakan bahwa prinsip-prinsip GCG berpengaruh positif pada kinerja keuangan PT Angkasa Pura II (persero). Begitu pula dengan Pradnyaswari dan Putri (2016) yang menyatakan bahwa prinsip-prinsip GCG berpengaruh positif pada kinerja keuangan koperasi di Kabupaten Klungkung. Beberapa penelitian berikutnya di antaranya Atmadja dkk. (2014) serta Dewi dan Putri (2014) mendapatkan hasil yang sama yaitu prinsip GCG berpengaruh positif pada kinerja perusahaan. Berdasarkan uraian mengenai teori keagenan dan hasil penelitian sebelumnya dapat merumuskan hipotesis pertama sebagai berikut.

$\mathrm{H}_{1}$ : Prinsip-prinsip GCG berpengaruh positif pada kinerja LPD se-Kota Denpasar.

Budaya THK dapat diartikan sebagai tiga penyebab kebahagiaan. Oleh karena itu, THK dapat memberikan panduan bagaimana manusia harus bersikap terhadap tiga hal, yang meliputi hubungan manusia dengan Tuhan Yang Maha Esa (parahyangan), hubungan manusia dengan manusia (pawongan), dan hubungan manusia dengan lingkungan (palemahan) agar manusia dapat mencapai kesejahteraan berkelanjutan (Agung, 2004).

Aspek Parahyangan berasal dari kata hyang yang berarti Hyang Widhi atau Tuhan. Parahyangan merupakan salah satu dimensi dari budaya THK yang menekankan bahwa kesejahteraan dicapai bila terealisasi hubungan harmonis antara manusia dengan Tuhan penciptanya (Ashrama, 2005). Dalam aspek ini pengelolaan perusahaan seharusnya memperhatikan adanya eksistensi dari perwujudan bangunan suci. Di tempat itu komunitas manusia dapat melakukan sujudnya kepada Tuhan. Sujud yang dilakukan adalah untuk keselamatan dirinya 
sendiri, yang tentu saja akan membawa implikasi terhadap keselamatan kerja, dan keselamatan perusahaan (Surya, 2014). Aspek kedua adalah aspek pawongan berasal dari kata wong (orang atau penduduk) dalam masyarakat. Dalam aspek ini, pengelola organisasi harus menghormati hak-hak individu sesama manusia, memandang sesama manusia sebagai individu yang setara dan sepadan. Oleh sebab itu, setiap individu dalam perusahaan diharapkan melakukan kewajiban yang sepadan untuk mencapai tujuan manajemen (Surya, 2014).

Dan aspek yang ketiga adalah aspek palemahan palemahan berasal dari kata lemah yang berarti tanah, tanah pekarangan, atau wilayah pemukiman. Secara umum, aspek palemahan merupakan dimensi yang berhubungan dengan aspek fisik dari lingkungan disekitar kita atau perusahaan (Ashrama, 2005). Dalam aspek ini, organisasi seharusnya memperhatikan lingkungan internal dan eksternal yang ada. Dalam konteks lingkungan internal, komponen organisasi dapat memperhatikan konsep Tri Mandala (penataan lingkungan sesuai konsep horizontal) atau konsep Tri Angga (konsep vertikal, yaitu memandang kawasan paling atas sebagai kawasan yang disucikan). Disamping itu diperlukan juga adanya perhatian yang memadai dari pihak manajemen terhadap masyarakat sekitar sehingga tidak menimbulkan kecemburuan sosial (Surya, 2014).

Budaya Tri Hita Karana adalah sebuah filosofi atau sering disebut sebagai filosofi masyarakat Hindu Bali (Dwirandra, 2011). Sebagai suatu filosofi, sering dikatakan bahwa THK adalah filosofi yang abstrak sehingga tidak bisa diukur. Pada kenyataan THK telah diterapkan dalam semua sistem sosial dan pada dasarnya dapat diukur. Windia dan Dewi (2007) menyebutkan bahwa THK pada 
dasarnya adalah filosofi universal yang pada hakikatnya ada dan dianut oleh masyarakat lain meskipun tidak beragama Hindu, tetapi justru hanya di Bali terdapat sistem sosial yang secara nyata dan sadar menerapkan filosofi tersebut. Filosofi tersebut juga sangat relevan dengan aktivitas usaha atau bisnis.

Berhasilnya penerapan GCG dalam sebuah organisasi dipengaruhi oleh berbagai faktor baik yang berasal dari dalam maupun luar organisasi. Budaya THK merupakan salah satu faktor yang mendukung berhasilnya penerapan GCG pada sebuah organisasi yang akan berdampak pada meningkatnya kinerja organisasi. Beberapa penelitian telah dilakukan untuk menguji bagaimana budaya THK menjadi pemoderasi untuk variabel yang mempengaruhi kinerja organisasi. Dalam Mustikayani dan Dwirandra (2016) budaya THK tidak memoderasi pengaruh kompleksitas tugas pada kinerja auditor, namun budaya THK memoderasi pengaruh tekanan waktu pada kinerja auditor. Puspitha dan Sujana (2016) menunjukkan bahwa budaya organisasi memperkuat pengaruh prinsipprinsip GCG pada kinerja perusahaan berbasis balanced scorecard pada BPR di Kabupaten Badung.

Keberadaan budaya THK di sebuah LPD akan mendukung terciptanya keharmonisan pada setiap kegiatan bisnis yang ada didalamnya. Budaya THK dalam hal ini menjadi hal yang melengkapi dan memberikan pemahaman bahwa segala sesuatu harus dilaksanakan dengan seimbang. Dengan penerapan tata kelola yang baik (GCG) disebuah LPD ditambah dengan budaya THK yang dijadikan sebagai landasan dalam setiap kegiatan bisnis yang dilakukan oleh para karyawan, maka diharapkan kinerja dari LPD tersebut dapat mencapai tingkatan 
yang maksimal yang nantinya akan menguntungkan bagi semua pihak baik agen yang dalam hal ini adalah pengawas dan pegawai serta prinsipal yang merupakan seluruh nasabah dan masyarakat desa adat.

Implementasi budaya THK di sebuah LPD akan mendukung terciptanya keharmonisan pada setiap kegiatan bisnis yang ada didalamnya. Sehubungan dengan itu dan berdasarkan berbagai hasil penelitian sebelumnya maka dirumuskan hipotesis kedua sebagai berikut.

$\mathrm{H}_{2}$ : Budaya THK memperkuat pengaruh prinsip-prinsip GCG pada kinerja LPD se-Kota Denpasar.

\section{METODE PENELITIAN}

Penelitian ini dilakukan pada LPD yang terdapat di Kota Denpasar. Teknik penyampelan atas responden dilakukan dengan teknik sampling jenuh atau dikenal dengan istilah sensus, di mana semua anggota populasi dijadikan sampel. Maka dalam penelitian ini sampel yang digunakan adalah seluruh LPD yang berada di Kota Denpasar yang berjumlah 35 LPD tersebut tersebar di empat kecamatan yaitu sebanyak 10 LPD di Kecamatan Denpasar Utara, 12 LPD di Kecamatan Denpasar Timur, 11 LPD di Kecamatan Denpasar Selatan, dan dua LPD di Kecamatan Denpasar Barat.

Pelaksanaan prinsip GCG pada sebagian besar perusahaan di Indonesia merupakan awal perubahan budaya kerja perusahaan. Dalam menilai prinsipprinsip GCG dari sebuah LPD bisa dilihat dari 5 aspek yang yaitu transparency, accountability, responsibility, independency dan fairness. GCG dalam penelitian ini diukur dengan menggunakan kuisioner yang terdiri atas empat pernyataan 
untuk tiap-tiap prinsip GCG, sehingga jumlah keseluruhan pernyataan adalah 20 (diadopsi dari Atmadja dkk., 2014). Budaya THK mengandung pengertian tiga penyebab kesejahteraan yang bersumber pada harmonisasi hubungan antara manusia dengan Tuhan Yang Maha Esa yang dikenal dengan istilah parahyangan, manusia dengan alam lingkungannnya yang dikenal dengan palemahan, dan manusia dengan sesamanya yang dikenal dengan istilah pawongan. Budaya THK dalam penelitian ini diukur dengan menggunakan kuisioner yang terdiri atas 13 pernyataan (diadopsi dari Suardikha, 2011). Masing-masing pernyataan memiliki lima opsi jawaban, mulai dari "sangat tidak setuju" sampai "sangat setuju," yang kemudian dikonversi menjadi angka dari satu untuk "sangat tidak setuju" sampai lima untuk jawaban "sangat setuju." Responden adalah Ketua LPD dan Ketua Badan Pengawas LPD, yang dijabat oleh Bendesa Adat setempat. Skor GCG dan THK untuk tiap-tiap LPD adalah rata-rata skor yang dihitung berdasarkan jawaban kedua responden tersebut.

Kinerja merupakan hasil yang dicapai dari perilaku anggota organisasi. Jadi kinerja organisasi merupakan hasil yang diinginkan organisasi dari perilaku orang-orang di dalamnya. Dalam penelitian ini, sesuai dengan Peraturan Gubernur Bali No. 11 Tahun 2013 tentang Lembaga Perkreditan Desa pasal 22, variabel kinerja diukur dengan 5 aspek yaitu kecukupan modal (CAR), kualitas aktiva produktif (KAP), manajemen, laba, dan likuiditas, yang dikenal dengan istilah CAMEL. Nilai CAMEL diperoleh dari laporan yang diterbitkan oleh LPLPD per Desember 2016. 
Data yang diperoleh dari hasil tabulasi memiliki perbedaan, dimana data yang dihasilkan dari hasil jawaban responden untuk mengukur variabel GCG dan Budaya THK menghasilkan data yang memiliki skala ordinal, sedangkan Kinerja LPD yang diukur menggunakan CAMEL yang diperoleh dari laporan LPLPD Kota Denpasar yang memiliki skala Interval. Untuk menyamakan skala dari ketiga variabel ini agar dapat dilaksanakan pengolahan data, data yang berskala ordinal ditransformasikan menjadi data interval dengan menggunakan Method of Succesive Interval (MSI) pada Microsoft Excel.

Teknik analisis data yang digunakan dalam penelitian ini adalah regresi linier sederhana untuk menguji pengaruh GCG pada kinerja LPD (hipotesis 1) dan moderated regression analysis untuk menguji apakah THK memoderasi pengaruh GCG pada kinerja LPD (hipotesis 2).

Model regresi yang digunakan untuk menguji hipotesis 1 dan hipotesis 2 adalah berturut-turut sebagai berikut.

$$
\begin{aligned}
& \text { Kinerja }=\beta_{0}+\beta_{1} \mathrm{GCG}+\mathrm{e} \ldots \ldots \ldots \ldots \ldots \ldots \ldots \ldots \ldots \ldots \ldots \\
& \text { Kinerja }=\beta_{0}+\beta_{1} \mathrm{GCG}+\beta_{2} \mathrm{THK}+\beta_{3} \mathrm{GCG}^{*} \mathrm{THK}+\mathrm{e}
\end{aligned}
$$

\section{HASIL DAN PEMBAHASAN}

Semua kuisioner, seluruhnya berjumlah 70 kuisioner, yang disebarkan kepada masing-masing Ketua LPD dan Ketua Badan Pengawas LPD kembali dan dapat digunakan. Jadi, usable response rate dalam penelitian ini mencapai 100 persen. Karakteristik responden dalam penelitian ini dilihat dari tingkat pendidikan terkahir yang ditempuh, dimana sebanyak 25 responden $(35,71$ persen $)$ 
berpendidikan terakhir SMA, sebanyak 5 responden (7,15 persen) berpendidikan Diploma 3, sebanyak 35 responden (50 persen) berpendidikan S1, 4 responden (5,71 persen) berpendidikan S2, dan 1 responden (1,43 persen) berpendidikan S3.

Uji instrumen yang digunakan dalam penelitian ini adalah uji validitas dan uji reliabilitas. Hasil uji validitas instrumen (kuisioner) menunjukkan seluruh nilai koefisien korelasi dari instrumen ini lebih besar dari 0,3 sehingga instrumen penelitian ini dinyatakan valid. Hasil uji reliabilitas menghasilkan nilai Cronbach's alpha lebih besar dari 0,6 sehingga instrumen penelitian dinyatakan reliabel (disajikan pada Tabel 1).

Tabel 1.

Uji Reliabilitas

\begin{tabular}{lcl}
\hline Instrumen & Cronbach's Alpha & Keterangan \\
\hline GCG & 0.905 & Reliabel \\
THK & 0.907 & Reliabel \\
\hline Sumber: Data primer diolah (2017). & &
\end{tabular}

Sebelum regresi dilakukan, terlebih dahulu dilakukan uji asumsi klasik. Model regresi yang baik adalah model regresi yang didalamnya tidak terdapat masalah data yang distribusinya tidak normal, masalah multikolineritas, dan masalah heteroskedastisitas. Untuk itu sebelum dilakukan uji model regresi harus dilaksanakan pengujian asumsi klasik terhadap model regresi yang akan digunakan. Apabila model regresi tidak lolos dalam pengujian ini maka model regresi tidak dapat digunakan. Uji normalitas bertujuan untuk menguji apakah residual berdistribusi normal. Pengujian normalitas data dilakukan dengan uji Kolmogorov-Smirnov yang menguji normalitas Persamaan (2). Hasil pengujian menghasilkan nilai $\mathrm{Z}$ sebesar 0,532 dengan signifikasi 0,939, yang berarti bahwa 
residual regresi berdistribusi normal. Hasil pengujian disajikan pada Tabel 2.

Tabel 2.

Hasil Uji Normalitas

\begin{tabular}{ll}
\hline & Unstandardized Residual \\
\hline $\mathrm{N}$ & 35 \\
Kolmogorov-Smirnov Z & 0,532 \\
Asymp.Sig (2-tailed) & 0,939 \\
\hline Sumber: Data primer diolah (2016). &
\end{tabular}

Uji heteroskedastisitas dimaksudkan untuk mengetahui apakah dalam model regresi terjadi ketidaksamaan varian. Pengujian dilakukan dengan menggunakan Uji Glejser. Uji Glejser meregres nilai absolut residual pada variabel bebas. Model regresi dinyatakan tidak mengandung masalah heteroskedastisitas apabila probabilitas hasil uji Glejser di atas tingkat kepercayaan lima persen (Ghozali, 2009). Berdasarkan hasil pengujian yang telah dilakukan dapat dinyatakan bahwa model regresi yang digunakan dalam penelitian ini bebas dari masalah heteroskedastisitas. Hasil Uji Glejser disajikan pada Tabel 3.

Tabel 3.

Hasil Uji Heteroskedastisitas

\begin{tabular}{lll}
\hline Variabel & Sig & Keterangan \\
\hline GCG & 0,235 & Bebas Heteroskedastisitas \\
THK & 0,705 & Bebas Heteroskedastisitas \\
GCG*THK & 0,555 & Bebas Heteroskedastisitas \\
\hline \multicolumn{2}{l}{ Sumber: Data primer diolah (2017). }
\end{tabular}

Uji multikolinearitas menguji apakah dalam model regresi terdapat korelasi antar variabel bebas. Pengujian multikolinearitas dilakukan berdasarkan nilai tolerance dan variance inflation factor (VIF). Berdasarkan hasil pengujian tersebut, dapat diketahui bahwa tidak ada variabel independen yang memiliki nilai 
tolerance kurang dari 0,10 dan nilai VIF lebih dari 10. Analisis ini menunjukkan bahwa tidak terdapat gejala multikolinearitas terhadap variabel penelitian, sehingga layak untuk digunakan dalam pengujian selanjutnya. Hasil pengujian disajikan pada Tabel 4.

Statistik deskriptif disajikan untuk memberikan informasi tentang karakteristik variabel penelitian. Tabel 5 menunjukka nilai rata-rata GCG adalah sebesar 74,82 yang lebih mendekati nilai maksimumnya daripada nilai minimumnya. Nilai ini menyatakan bahwa responden memberikan pendapat dengan skor mendekati maksimal. Ini mengindikasikan bahwa LPD di Kota Denpasar sudah menerapkan prinsip-prinsip GCG dengan baik disetiap proses bisnis yang dilakukan.

Tabel 4.

Hasil Uji Multikolinearitas

\begin{tabular}{lll}
\hline Variabel & Tolerance & VIF \\
\hline GCG & 0,603 & 1,659 \\
THK & 0,603 & 1,659 \\
\hline \multicolumn{2}{l}{ Sumber: Data primer diolah $(2017)}$.
\end{tabular}

Tabel 5.

Statistik Deskriptif

\begin{tabular}{llllll}
\hline & N & Minimum & Maksimum & Rata-rata & $\begin{array}{l}\text { Deviasi } \\
\text { Standar }\end{array}$ \\
\hline GCG (X1) & 35 & 59,69 & 84,30 & 74,82 & 6,63 \\
THK (X2) & 35 & 36,24 & 54,06 & 48,32 & 4,89 \\
Kinerja LPD & 35 & 70,56 & 99,40 & 93,44 & 7,18 \\
\hline Sumber: Data &
\end{tabular}

Sumber: Data primer diolah (2017).

Nilai rata-rata budaya THK sebesar 48,32 menunjukkan secara rata-rata jawaban responden cenderung hampir sama dengan nilai maksimum. Nilai rata- 
rata yang mendekati nilai maksimum mengindikasikan bahwa seluruh LPD yang ada di Kota Denpasar telah cukup melaksanakan dan menerapkan Budaya THK dalam setiap aktivitasnya dalam organisasi.

Nilai rata-rata Kinerja LPD adalah 93,44 yang hampir mendekati nilai skor maksimum, mengindikasikan bahwa rata-rata kinerja LPD menunjukkan kinerja yang sehat walaupun pada kenyataannya masih terdapat dua LPD yang termasuk dalam kategori cukup sehat.

Tabel 6 menyajikan hasil pengujian hipotesis pertama. Koefisien determinasi (adjusted $\mathrm{R}^{2}$ ) mengukur seberapa jauh kemampuan model dalam menerangkan variabel-variabel dependennya (Ghozali, 2009). Nilai adjusted $\mathrm{R}^{2}$ adalah sebesar 0,488 yang berarti sebesar 48,8 persen variabel terikat kinerja LPD dapat dijelaskan oleh variabel GCG sedangkan sisanya sebesar 51,2 persen dipengaruhi oleh variabel lain yang tidak termasuk dalam model. Nilai $F_{\text {hitung }}$ sebesar 33,460 dengan signifikansi lebih rendah dari 0,05 menunjukkan bahwa model regresi layak untuk digunakan menjelaskan variabel dependen.

Tabel 6.

Analisis Regresi Linier Sederhana

\begin{tabular}{lrrrrr}
\hline \multirow{2}{*}{ Variabel } & \multicolumn{2}{c}{ Unstandardized Coefficient } & $\begin{array}{c}\text { Standardized } \\
\text { Coefficient }\end{array}$ & t-hitung & Sig. \\
\cline { 2 - 5 } & B & Std. Error & Beta & & \\
\hline Constant & 35,876 & 9,989 & - & 3,592 & 0,001 \\
GCG & 0,769 & 0,133 & 0,710 & 5,784 & 0,000 \\
\hline $\mathrm{R}^{2}$ & & 0,710 & & \\
Adjusted $\mathrm{R}^{2}$ & & 0,488 & & \\
$\mathrm{~F}_{\text {hitung }}$ & & 33,460 & & \\
Sig. F & 0,000 & & \\
\hline
\end{tabular}

Variabel dependen: Kinerja LPD.

Sumber: Data primer diolah (2017). 
Nilai $t_{\text {hitung }}$ sebesar 5,784 dengan tingkat signifikasi 0,000 (lebih rendah dari $\alpha 0,05)$ menunjukkan dukungan atas hipotesis pertama, yaitu GCG berpengaruh positif pada Kinerja LPD di Kota Denpasar. Nilai beta sebesar 0,710 berarti bahwa setiap kenaikan GCG sebesar satu satuan akan diikuti dengan kenaikan Kinerja sebesar 0,710.

Hipotesis kedua diuji dengan moderated regression analysis (MRA) dengan menggunakan Persamaan (2). Hasil pengujian tersebut disajikan pada Tabel 7.

Tabel 7.

Uji Moderated Regression Analysis (MRA)

\begin{tabular}{|c|c|c|c|c|}
\hline & Unstandardized coefficient & Standardi & & \\
\hline Variabel & & $\begin{array}{r}\text { zed } \\
\text { Coefficie }\end{array}$ & t-hitung & Sig. \\
\hline
\end{tabular}

\begin{tabular}{|c|c|c|c|c|c|}
\hline & B & Std. Error & & & \\
\hline Constant & 39,011 & 10,461 & - & 3,729 & 0,001 \\
\hline GCG & 0,341 & 0,153 & 0,315 & 2,225 & 0,033 \\
\hline THK & 0,574 & 0,199 & 0,391 & 2,889 & 0,007 \\
\hline $\begin{array}{l}\text { GCG*TH } \\
\mathrm{K}\end{array}$ & 1,790 & 0,847 & 0,267 & 2,114 & 0,043 \\
\hline $\mathrm{R}^{2}$ & & 0,822 & & & \\
\hline Adjusted $\mathrm{R}^{2}$ & & 0,643 & & & \\
\hline $\mathrm{F}_{\text {hitung }}$ & & 21,456 & & & \\
\hline Sig. F & & 0,000 & & & \\
\hline
\end{tabular}

Sumber: Data primer, diolah (2017).

Tabel 7 menunjukkan nilai Adjusted $\mathrm{R}^{2}$ adalah 0,643 yang berarti sebesar 64,3 persen Kinerja LPD dapat dijelaskan oleh variabel dalam model regresi, sedangkan sisanya sebesar 35,7 persen dipengaruhi oleh variabel lain yang tidak diperhitungkan dalam model penelitian ini. Uji kelayakan model (Uji F) dilakukan untuk mengetahui apakah model yang digunakan dalam penelitian ini merupakan 
model fit (model yang layak) dengan melihat nilai $F_{\text {hitung }}$ dan tingkat signifikansinya. Tabel 7 menunjukkan nilai $F_{\text {hitung }}$ sebesar 21,456 dengan tingkat signifikansi 0,000 (lebih kecil dari $\alpha$ 0,05). Dengan demikian model penelitian ini layak digunakan untuk melakukan pembuktian atas hipotesis penelitian.

Penerimaan atau penolakan hipotesis 2 dilakukan berdasarkan signifikansi

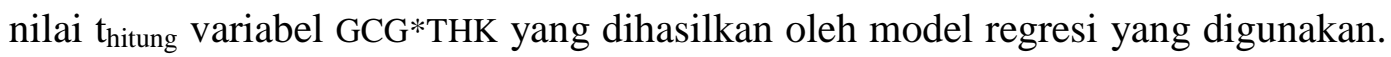
Tabel 7 menunjukkan bahwa nilai tersebut adalah 2,114 (nilai positif) dengan signifikansi 0,043 , yang lebih rendah dari tingkat $\alpha$ sebesar 0,05 . Dengan demikian maka dapat dinyatakan bahwa hipotesis 2 yang menyatakan bahwa THK memperkuat pengaruh GCG pada Kinerja LPD diterima.

Pembahasan hasil pengujian hipotesis selanjutnya dijelaskan secara rinci untuk mengetahui hasil penelitian, alasan, serta persamaan dan perbedaan penelitian ini dengan penelitian sebelumnya yang pernah dilakukan terkait dengan penelitian ini. Hasil analisis regresi linier sederhana pada Tabel 6 menunjukkan bahwa GCG berpengaruh positif pada kinerja LPD se-kota Denpasar. Teori agensi menyatakan dengan adanya penerapan prinsip GCG pada LPD yang ada di Kota Denpasar maka konflik keagenan yang terjadi antara agen dan prinsipal dapat diminimalisir. Penerapan prinsip-prinsip GCGdalam pengelolaan LPD juga akan mempengaruhi bisnis LPD untuk berjalan lebih transparan dan akuntabel. Selain itu, diharapkan pula LPD lebih memiliki rasa tanggung jawab kepada para pemangku kepentingan, selalu bersikap independen untuk menjaga tingkat profesionalisme sehingga tidak ada pihak yang dirugikan. 
Berdasarkan hasil MRA pada Tabel 7, hasil uji hipotesis menunjukkan bahwa pengaruh GCG pada kinerja LPD meningkat setelah diinteraksikan dengan budaya THK. Hasil pengujian tersebut menunjukka bahwa peran moderasi variabel budaya THK pada variabel GCG adalah bersifat memperkuat, artinya penerapan GCG yang semakin baik dengan diikuti oleh penerapan budaya THK akan secara bersama-sama meningkatkan kinerja LPD di kota Denpasar. Budaya THK memberikan pandangan bahwa dalam setiap proses bisnis serta dalam pengambilan keputusan harus didasarkan kepada tiga hal yaitu palemahan, pawongan serta palemahan. Dalam setiap elemen ini harus berjalan secara bersamaan dan harus dijaga keharmonisannya. Walaupun dapat dikatakan penerapan budaya THK sudah menjadi dasar dari aktivitas bisnis LPD dari awal berdirinya, namun apabila dilaksanakan secara bersama-sama dengan penerapan tata kelola yang baik atau GCG memang memiliki pengaruh yang tidak saling bertolak belakang. Pada kenyataannya perpaduan dari kedua hal tersebut menghasilkan kinerja yang lebih baik.

\section{SIMPULAN DAN SARAN}

Berdasarkan hasil analisis variabel GCG dan budaya THK pada kinerja LPD se-kota Denpasar, dapat disimpulkan bahwa GCG berpengaruh positif pada kinerja LPD di Kota Denpasar. Hasil ini berarti bahwa semakin baik penerapan GCG maka kinerja LPD juga mengalami peningkatan. Dengan kata lain, dengan penerapan tata kelola yang baik. 
Hasil pengujian menunjukkan bahwa budaya THK memperkuat pengaruh dari GCG pada kinerja LPD. Hasil pengujian tersebut mengindikasikan bahwa peran moderasi variabel budaya THK pada GCG adalah bersifat memperkuat, artinya penerapan GCG yang semakin baik dengan diikuti oleh penerapan budaya THK akan secara bersama-sama meningkatkan kinerja LPD di kota Denpasar.

Sesuai simpulan penelitian maka dapat disarankan agar LPD senantiasa menerapkan prinsip-prinsip GCG dengan baik untuk meningkatkan kinerjanya. Selain itu, penerapan budaya THK juga sangat disarankan karena akan memperkuat pengaruh GCG pada kinerja LPD.

Responden dalam penelitian ini dibatasi pada ketua LPD dan ketua badan pengawas LPD. Penelitian selanjutnya dapat mempertimbangkan untuk mengukur penerapan konsep THK dengan melibatkan seluruh pemangku kepentingan di desa adat setempat. Nilai adjusted $\mathrm{R}^{2}$ sebesar 0,643 yang berarti bahwa terdapat 35,7 persen pengaruh variabel lain yang tidak diperhitungkan dalam model penelitian ini juga memberi ruang bagi peneliti selanjutnya untuk mengembangkan penelitian ini dengan mempertimbangkan variabel-variabel lain yang dapat mempengaruhi kinerja LPD.

\section{REFERENSI}

Adiputra, I M. P. 2014. Budaya Tri Hita Karana Sebagai Pemoderasi Pengaruh Kompleksitas Tugas terhadap Kinerja Internal Auditor (Studi Pada Kantor Inspektorat di Provinsi Bali). Jurnal Dinamika Akuntansi. 6 (2):191-206.

Adnyana, P. 2016. Tri Hita Karana dalam Agama Hindu. http://babadbali.com/canang-sari/2016/tri-hita-karana-dalam-agama-hindu/ diunduh tanggal 21 Juli 2016. 
Ahmad, M. S. 2012. Impact of Organizational Culture on Performance Management Practices in Pakistan. Business Intelligence Journal, 5 (1): $50-55$.

Agung, A.A.G. 2004. Tri Hita Karana. kompas.com. (diunduh tangggal 30 Agustus 2016).

Apriliana, I N.D.R dan Utama, I M. K. 2013. Pengaruh Rasio CAMEL dan Pengungkapan Sukarela pada Tingkat Kepercayaan Nasabah LPD di Kabupaten Klungkung. E-Jurnal Akuntansi Universitas Udayana. 3 (3): 179-197.

Ashrama, Berata. 2005. Implementasi Konsep Tri Hita Karana pada Beberapa Hotel di Bali. Thesis. Universitas Udayana.

Atmadja, A. T., Darmawan, N. A. S. dan Saputra, K. A. 2014. Pengaruh Implementasi Good Corporate Governance dan proteksi Awig-Awig terhadap Kinerja Lembaga Perkreditan Desa (LPD) dengan Budaya Menyama Braya sebagai Variabel Moderasi. www.multiparadigma.lecture.ub.ac.id. (diunduh tanggal 24 Mei 2016).

Budiarti, I. 2010. Penerapan Prinsip-prinsip Good Corporate Governance Pada Dunia Perbankan. Jurnal Manajemen. 8(1): 70-89.

Dewi, K. K. dan Putri, I G. A. M. A. 2014.Pengaruh Penerapan Prinsip-Prinsip GCG pada Kinerja Keuangan Lembaga Perkreditan Desa Kabupaten Gianyar, Provinsi Bali. E-jurnal akuntansi Universitas Udayana, 8 (1): 7082.

Dwirandra, A. A. N. B. 2011. Rekontruksi Metoda Penilaian Aset dengan Filosofi Tri Hita Karana. Disertasi. Universitas Brawijaya.

Eisenhardt, K. (1989). Agency Theory: An Assesment and Review. Academy of Management Review. 14: 57-74.

Ehtesham, U. M., Muhammad, T. M., dan Muhammad, S. A. 2011. Relationship Between Organizational Culture and Performance Management Practices: A Case of University in Pakistan. Journal of Competitivenesess, 4: 78-86.

Ghozali, I. 2009. Aplikasi Analisis Multivariate dengan program SPSS, Edisi IV. Semarang: Badan Penerbit Universitas Diponegoro.

Gunawan, K. 2009. Pengaruh Budaya Organisasi, Kepuasan Kerja dan Motivasi Kerja terhadap Gaya Kepemimpinan dan Kinerja Organisasi (Studi pada Lembaga Perkreditan Desa (LPD) di Bali). Disertasi. Universitas Brawijaya.

Haque, F., Arun, T., \& Kirkpatrick, C. 2008. Corporate Governance and Capital Markets: 
A conceptual framework. White paper. Heriot-Watt University.

Hartono, D. F. dan Nugrahanti, Y. W. 2014. Pengaruh Mekanisme Corporate Governance Terhadap Kinerja keuangan Perusahaan Perbankan. Jurnal Dinamika Akuntans dan Perbankan, 3 (2): 1-22.

Jensen, M. C. dan Meckling, W. H. 1976. Theory of the Firm: Managerial Behavior, Agency Costs and Ownership Structure. Journal of Financial Economics, 3 (4): 305-360.

Kautsar, A. dan Kusumaningrum, T. M. 2015. Analisis Pengaruh Good Corporate Governance Terhadap Kinerja Perusahaan yang Dimediasi Struktur Modal Dapa Perusahaan Pertambangan yang Listed di BEI 2009-2012. Journal of Research in Economics and Management, 15 (1): 29-75.

Khan, H. 2011. A Literature Review of Corporate Governance. International Conference on E-Business, Management and Economics. 25: 1-5.

Komite Nasional Kebijakan Governance (KNKG). 2006. Pedoman Umum Good Corporate governance Indonesia, Jakarta.

Lembaga Pemberdayaan Lembag Perkreditan Desa. 2016. Laporan LPLPD Kota Denpasar per 31 Desember 2016. Denpasar: LPLPD Kota Denpasar.

Mustikayani, N L. P. D. dan Dwirandra, A. A. N. B. 2016. Budaya Tri Hita Karana Sebagai Pemoderasi Kompleksitas Tugas dan Tekanan Waktu terhadap Kinerja Auditor. E-jurnal Akuntansi Universitas Udayana, 16 (2): 1544-1573.

Ozigbo, N. C. 2016. Impact of Organizational Culture and Technology on Firm Performance in Service Sector. Communication of the IIMA, 13 (6): 68-82.

Peraturan Gubernur Bali Nomor 11 Tahun 2013 Tentang Petunjuk Pelaksanaan Peraturan Daerah Provinsi Bali Nomor 8 Tahun 2002 Tentang Lembaga Perkreditan Desa Sebagaimana Telah Diubah Beberapa Kali Terakhir dengan Peraturan Daerah Provinsi Bali Nomor 4 Tahun 2012 Tentang Perubahan Kedua Atas Peraturan Daerah Provinsi Bali Nomor 8 Tahun 2002 Tentang Lembaga Perkreditan Desa.

Pradnyaswari, L. G. D. A dan Putri, I G. A. M. A. D. 2016. Pengaruh PrinsipPrinsip Good Corporate Governance pada Kinerja Keuangan Koperasi di Kabupaten Klungkung. E-jurnal Akuntansi Universitas Udayana, 14 (2): 1064-1091.

Puspitha, M. Y. dan Sujana, I K. 2016. Budaya Organisasi Pemoderasi Pengaruh Prinsip Good Corporate Governance pada Kinerja Perusahaan Berbasis 
Balanced Scorecard. E-Jurnal Akuntansi Universitas Udayana, 14 (3): 1978-2012.

Putri, IG.A.M.A.D. 2012. Peranan Good Corporate Governance dan Budaya terhadap Kinerja Organisasi. Audi Jurnal Akuntansi \& Bisnis. 7 (2): 193-204.

Rahmatika, N., Kirmizi, dan Agus, R. 2015. Pengaruh Penerapan Prinsip-Prinsip Good Corporate Governance Terhadap Kinerja Keuangan Perusahaan (Studi pada PT Angkasa Pura II). Jurnal Akuntansi (Media Riset Akuntansi dan Keuangan). 3 (2): 148-156.

Riana, I G. 2010. Dampak Penerapan Budaya Tri Hita Karana terhadap Orientasi Kewirausahaan dan Orientasi Pasar serta Konsekuensinya pada Kinerja Usaha dengan Moderator Pembelajaran Bisnis. Disertasi. Universitas Brawijaya.

Sarbah, A. dan Xiao,W. 2015. Good Corporate Governance Structure: A Must For Family Businesses. Open Journal of Business and Management, 3: 40-57.

Shleifer, A. dan Vishny, R. W. 1997. A Survey of Corporate Governance. Journal of Finance, 52 (2): 737-783.

Suardikha, I M. S. 2011. Pengaruh Implementasi Budaya Tri Hita Karana terhadap Penggunaan Sistem Infromasi Akuntansi dimediasi Keyakinan Diri atas Komputer, Keinovatifan Personal, Persepsi kegunaan, dan Persepsi Kemudahan Penggunaan pada Bank Perkreditan Rakyat di Bali. Disertasi. Universitas Brawijaya.

Surya, I. B. K., Thoyib, A., Fatchan, A., dan Rahayu, M. 2014.Tri Hita Karana Culture Effect on Company Performance, Leadership and Organizational Commitment (Studies an Regional Water Company in Bali Province). International Journal of Business and Management Invention, 3 (6): 1322.

Suryadi, A. dan Rosyidi, H. 2013. Kinerja Karyawan Ditinjau dari Analisis Faktor Budaya Perusahaan. Jurnal Penelitian Psikologi, 4 (2): 166-180.

Tenaya, G. A. I. 2007. Analisis Falsafah dan Konsep Akuntansi dalam Perspektif Filsafat Kultur Bali Tri Hita Karana dan Kesadaran Internal Lembaga terhadap Hukum Perusahaan. Thesis. Universitas Brawijaya.

Thuraisingam, M. R. 2013. The Effect of Corporate Governance on Company Performance: Evidence From Sri Lankan Financial Services Industry. Journal of Economics and Sustainable Development, 4 (17): 103-110. 
Todorovic, I. 2013. Impact of Corporate Governance on Performance of Companies. Monyenegrin Journal of Economics, 9 (2): 47-53.

Windia, W. dan Dewi, R. K. 2007. Analisis Bisnis yang Berlandaskan Tri Hita Karana. Denpasar: Universitas Udayana.

Yudana, P. I., Cipta, W., dan Suwendra, I W. 2015 Pengaruh Kredit Bermasalah dan Perputaran Kas terhadap Likuiditas pada Lembaga Perkreditan Desa Kecamatan Seririt. E-journal Bisma Universitas Pendidikan Ganesha, 3 (tanpa halaman). 